\title{
A fresh approach to the pathogenesis of pancreatitis
}

\author{
A. D. McCUTCHEON \\ From the Baker Medical Research Institute, Melbourne, Australia, and Alfred Hospital, Melbourne, \\ Australia
}

The pathogenesis of pancreatitis has remained a confused subject in spite of extensive investigation and the advancement of numerous theories. There are two main reasons for this. 1 The persistent belief that obstruction of the pancreatic duct is a major cause of pancreatitis when the bulk of experimental and pathological evidence is against this possibility. 2 The failure to distinguish between aetiological factors (alcohol, gallstones) and the mechanism by which these factors produce pancreatitis.

Thus Warren (1961a) has suggested that 'the continued search for a single aetiological agent in the genesis of acute and chronic pancreatitis is illusory': this statement is obviously correct in relation to the aetiological factors mentioned but it may not be true for the mechanism. In this paper a unifying concept of pathogenesis is presented which is compatible with known clinical and experimental facts and suggests new possibilities in the relationship between biliary tract disease and pancreatitis.

Many authors regard acute and chronic pancreatitis as different stages of the one disease (Comfort, Gambill, and Baggenstoss, 1946; Hess, 1965): others have given evidence that these are separate entities with different aetiologies (Sarles, Sarles, Camatte, Muratore, Gaini, Guien, Pastor, and Le Roy, 1965). In view of this uncertainty and the fact that the mechanism of pathogenesis is obscure in both instances, both types must be considered in any discussion of the pathogenesis of pancreatitis. The simplest terminology to follow is that adopted by participants in the symposium held in Marseilles in 1963 (Bockus, 1965), namely, (1) acute pancreatitis and relapsing acute pancreatitis, and (2) chronic pancreatitis and relapsing chronic pancreatitis (chronic pancreatitis with acute exacerbations). The essential difference between 1 and 2 is the presence of permanent residual damage in both chronic varieties.

\section{CURRENT THEORIES OF MECHANISM}

Most authors consider that acute pancreatitis results 'Postal address: Commercial Road, Prahran 3181, Victoria, Australia. from obstruction to the pancreatic duct in the presence of an actively secreting pancreas (Lium and Maddock, 1948; Wainwright, 1951; Dunphy, Brooks, and Achroyd, 1953; Jones, Smith, and Gregory, 1958; Johnson and Kalser, 1959; Gross and Hallenbeck, 1960; Bartlett and Nardi, 1960; Block and Paloyan, 1963; Nardi, 1963). The evidence against this theory is as follows.

Organic obstruction of the pancreatic duct is not present in the majority of cases (Longmire and Wallner, 1956; McCutcheon, 1962): a recent review of 100 fatal cases of acute pancreatitis showed that an obstructive mechanism could be demonstrated in only three (Shader and Paxton, 1966). Dunphy et al. (1953) described eight cases of postoperative pancreatitis and were able to exclude ductal obstruction in six. Rich and Duff (1936) described metaplasia of the epithelium in branches of the pancreatic duct leading to partial obstruction and dilatation of acini. Others have shown that duct metaplasia is a common finding in normal glands (Wainwright, 1951; Jones and Smith, 1952) and that it tends to produce atrophy of related acini rather than acute inflammation (Sinclair, 1959).

Ligation of the major pancreatic duct in cats, dogs, and rabbits produces atrophy of acini without pancreatitis (Wang, Wang, and Grossman, 1950; Wang, Strauss, and Adlersberg, 1958; Radakovich, Pearse, and Strain, 1952; Becker and Schaefer, 1957), and it has been used to prevent haemorrhagic pancreatitis occurring in dogs with a closed duodenal loop (McCutcheon and Race, 1962). Neoplasms of the head of the pancreas cause ductal obstruction in association with normal stimulation of the pancreas by ingestion of food and these patients rarely have concomitant acute pancreatitis (Brunschwig, 1949). Only 15 out of 100 patients with stenosis of the sphincter of Oddi showed some evidence of pancreatitis (Cattell, Colcock, and Pollack, 1957).

Popper and Necheles (1942) produced extensive oedema of the pancreas in dogs by ligating a pancreatic duct and stimulating the gland by secretin; the oedema disappeared after four hours and 
haemorrhagic pancreatitis did not occur. Similar results were obtained by Radakovich et al. (1952), by Block, Wakim, and Baggenstoss (1954) and by Powers, Brown, and Stein (1955). Popper, Necheles, and Russell (1948) showed that temporary occlusion of the main pancreatic artery was necessary to transform pancreatic oedema into pancreatic necrosis. Thal, Perry, and Egner (1957) have concluded that 'experiments designed to produce maximum secretory activity in the presence of complete duct obstruction have uniformly failed to produce pancreatic necrosis'. It does not seem to be generally appreciated that pancreatic oedema from duct obstruction is a different thing from pancreatic oedema due to vascular obstruction in pancreatitis.

Deliberate ligation of pancreatic ducts has been attempted in 17 patients with relapsing pancreatitis with varying success (Howard and Jordan, 1960). The significant fact which emerged was that none of the patients developed pancreatitis in the immediate postoperative period. This would seem to be a convincing demonstration that 'obstruction of the pancreatic duct has little to do with the aetiology of pancreatitis' (McCutcheon, 1964).

The obstruction-hypersecretion theory fails to account for the activation of pancreatic enzymes in the presence of normal inhibitors (Dreiling, 1961) which occurs in acute pancreatitis. This problem is discussed later.

Similar facts emerge in studying chronic pancreatitis and relapsing pancreatitis. Edmondson, Bullock, and Mehl (1949) studied 62 cases of chronic pancreatitis; dilatation of the ducts was common but no evidence of stricture was found (also Berens, Baggenstoss, and Gray, 1954). Elmslie and White (1965) did 13 operative pancreatograms in 14 patients with chronic recurrent pancreatitis and nine showed no evidence of obstruction within the pancreatic duct; they assumed that obstruction must be present at the ampullary sphincter (also Pollock, 1958). Janowitz and Dreiling (1959) noted similar findings and considered that dilatation of the pancreatic duct might be due to ectasia resulting from destruction of periductal supporting tissue similar to that seen in bronchiectasis. Janowitz and Dreiling reported three other significant facts. The total pancreatic secretion and rate of flow in patients with chronic pancreatitis are far greater than one would expect and in the average case this speaks against fixed obstruction to flow' (also Goldstein, Wirts, Cozzolino, and Menduke, 1964). Biliary flow following secretin stimulation is less in normal individuals than in patients with pancreatitis, again providing no evidence of obstruction by spasm. Deliberate stimulation of the pancreas by secretin in the early stages of acute pancreatitis in man does not cause an exacerbation of the disease (Dreiling and Janowitz, 1962).

Pancreatic duct obstruction is undoubtedly present in a number of advanced cases of chronic pancreatitis (Warren, 1959; Thal, Goott, and Margulis, 1959; Warren and Veidenheimer, 1962). Multiple points of obstruction give the 'chain of lakes' appearance and drainage operations afford considerable relief from pain (DuVal, 1954; Silen, Baldwin, and Goldman, 1963). The major site of obstruction is several centimetres from the duodenum and not at the ampulla of Vater. The time sequence indicates that these strictures are a result of repeated pancreatic inflammation rather than the cause. Egdahl (1964) has described this progression of events in a patient undergoing sphincteroplasty for pancreatitis; the original operative pancreatogram was normal and 12 months later, after recurrent episodes of pancreatitis, another pancreatogram showed multiple strictures of the duct (also Sarles et al., 1965).

In view of all the evidence outlined here it is quite remarkable that the obstruction-hypersecretion theory should be considered tenable at all. The reasons for its dominance are probably the apparent lack of a better mechanism and the predominantly surgical approach to the problem of pancreatitis.

COMMON CHANNEL THEORY The theory of biliary reflux along a common channel was originally suggested by Opie (1901b). In its more modern form (Elliott, Williams, and Zollinger, 1957) this theory proposes that pancreatic juice, passing via a common channel into the common bile duct, is activated in the bile and the bile-enzyme mixture may then infiltrate the pancreatic duct at low pressure causing haemorrhagic pancreatitis. The evidence against this theory has been summarized elsewhere (McCutcheon, 1962 and 1964) but will be stated again briefly.

A common channel does not exist in the majority of cases of pancreatitis (McCutcheon, 1962).

The pressure within the pancreatic ductal system is higher than in the common bile duct and there is no evidence for reversal of flow if biliary pressure is artificially increased (Anderson, Mehn, and Method, 1960; Elmslie, White, and Magee, 1966).

Biliary reflux is seen often during T-tube cholangiography and is harmless (Hicken and McAllister, 1952); under these conditions abnormal pressures are created at the lower end of the bile duct. In contrast, reflux of dye into the pancreatic duct rarely occurs during intravenous cholangiograms when abnormal pressures are not generated at the papilla (McDonough and Wise, 1955; Dreiling, Janowitz, and Perrier, 1964). The assumption that bile often refluxes into the pancreatic duct under 
normal circumstances is therefore quite unjustified.

Many workers have shown that bile may be diverted into the pancreatic duct without causing pancreatitis, provided physiological pressures are not exceeded (Nordmann, 1913; Thal et al., 1957; White and Magee, 1960).

Bile does not activate pancreatic proteolytic enzymes (Haverback, Dyce, Bundy, and Edmondson, 1960).

In most cases of pancreatitis there is no evidence of obstruction at the papilla to cause reflux. Spasm of the sphincter of Oddi has been invoked as the cause of obstruction but it has been clearly demonstrated that spasm closes both ducts, making a common channel impossible (Judd, 1921; Caroli, Porcher, Pequignot, and Delattre, 1960; PaulinoNetto and Paulino, 1963).

The creation of an artificial common channel may lead to pancreatitis in the presence of infection (Hermann and Knowles, 1965) or under circumstances which allow the activation of pancreatic enzymes (Powers et al., 1955). The general consensus of opinion is that infection plays an insignificant role in the pathogenesis of ordinary acute pancreatitis (Ivy and Gibbs, 1952; Dreiling, 1958).

PRESENT APPROACH If current theories are untenable a fresh approach is necessary to the problem of the pathogenesis of pancreatitis. When this study began over 10 years ago, two facts stood out. (1) Active pancreatic enzymes could produce all the features of acute haemorrhagic pancreatitis without invoking other factors. (2) Pancreatic proteolytic enzymes were activated only by contact with duodenal secretions. Therefore reflux of duodenal contents into the pancreatic duct provided a rational and simple explanation for the activation of enzymes and the subsequent pathological changes. A search of the early literature on pancreatitis revealed that this was a rediscovery of an old idea.

Opie (1901a) referred to a suggestion by Hlava that gastric juice may be driven into the pancreatic duct. Williams and Busch (1907) thought that the passage of gallstones might result in dilatation of the ampulla of Vater followed by reflux of intestinal contents; they performed a number of experiments designed to test this hypothesis. In the second edition of his book Opie (1910) discussed fully this theory and concluded that 'it is well known that increased pressure within the duodenum does not force duodenal contents into the bile duct or into the pancreatic duct after death'. At the same time Opie's common channel theory was gaining acceptance.

Eve (1915) summarized the evidence against the theory of duodenal reflux, and Dragstedt, Haymond, and Ellis (1934) noted the failure to produce pan- creatitis by injection of trypsinogen activating substances into the pancreatic duct. Archibald (1919) reported experiments in which he found it impossible to force fluid from the duodenum into either the common bile duct or pancreatic duct after one hour's sustained pressure. Since then the theory has been ignored except for occasional references (Joshi, Probstein, and Blumenthal, 1957). It was revived in a recent series of papers (McCutcheon, 1962, 1964; McCutcheon and Race, 1962, 1963) and the evidence will now be reviewed and extended.

Acute haemorrhagic pancreatitis which closely resembles human pancreatitis may be produced in dogs by creating a closed duodenal loop (Pfeffer, Stasior, and Hinton, 1957). The loop becomes distended and haemorrhagic and the authors attributed the pancreatic lesion to vascular engorgement and obstruction. Paulino-Netto and Dreiling (1960), using the same technique, considered that pancreatic ductal hypertension was the primary cause of pancreatitis and that vascular interference played a secondary role. McCutcheon and Race (1962) showed that the pancreatitis was due to reflux of duodenal contents into the pancreatic ducts and that it failed to develop if the pancreatic ducts were ligated; reflux of barium particles was demonstrated. Their results were confirmed by Wisniewski, Williams, and MacKenzie (1963) and by Byrne, Reilly, and Toutounghi (1964) who used gentian violet to show the reflux. More recently Strack, Dreizin, Ketyer, and Lazaro (1967) postulated a different mechanism, 'involvement of the head of the pancreas by the transudation of intraduodenal contents', but their findings are negated by the fact that ligation of pancreatic ducts prevents the development of pancreatitis in spite of the usual changes developing in the closed duodenal loop.

These experiments have proved not only that reflux of duodenal contents can occur in vivo but that such reflux may cause haemorrhagic pancreatitis. They have a peculiar significance for the human disease because pancreatitis may complicate gastroenterostomy or a Polya gastrectomy when there is obstruction of the afferent loop (Perman, 1935). Wallensten (1958) recorded 12 deaths from acute postoperative pancreatitis out of 1,769 patients with Polya type gastrectomies, and no deaths from pancreatitis in 605 patients having Billroth I resections. The marked difference in these figures was attributed to the occasional transformation of the afferent loop into a blind sac; here the conditions are almost identical with those in the dog experiments and there is little doubt that reflux of duodenal contents into the pancreatic duct is the mechanism responsible for pancreatitis in both instances. 
In view of the criticisms of the other theories it may be claimed that this is the first definite demonstration of a mechanism responsible for causing haemorrhagic pancreatitis in man. Numerous other examples of pancreatitis associated with duodenal obstruction could be cited (Wilkie, 1921; Perry, 1954; Dreiling, Kirschner, and Nemser, 1960). The cases reported by Hinshaw, Carter, Baker, and Wise (1960) probably belong to this category although the pancreas was not haemorrhagic in three out of four cases. Austen and Baue (1964) found that pancreatitis did not occur following gastric resection if the duodenal stump was drained by a catheter.

Byrne and Joison (1964) consider that bacteria play a primary role in the pathogenesis of closed duodenal loop pancreatitis; they found that a variety of antibiotics introduced into the loop before closure would prevent the onset of haemorrhagic pancreatitis although some changes were still seen; gentian violet had a similar effect (Byrne et al., 1964). In these experiments, however, the pancreatic ducts were not sectioned and McCutcheon and Race (1962) have shown that they may become blocked by debris or particulate matter, thus preventing the development of pancreatitis. Another factor to consider is the possible antiproteolytic action of gentian violet and some of the antibiotic drugs. Recent experiments have shown that haemorrhagic pancreatitis is produced by the closed duodenal loop technique in germ-free dogs (Nance and Cain, 1967).

Reflux of duodenal contents into the pancreatic duct is normally prevented by a number of mechanisms: the oblique course of the duct which bends and narrows as it passes through the layers of duodenal muscle; the constricting effect of the intestinal muscle; the sphincter of Oddi; and mucosal folds or valvules which block the entrance to the pancreatic duct. Thus distension of the duodenum for a short time, in healthy males, does not cause reflux into the pancreatic duct (Greenfield, Siegel, and De Francis, 1955).

Echenberg and Brown (1963) have described the transverse mucosal folds and pouches which are associated exclusively with the termination of the pancreatic duct: they have been noted by many authors, they occur in several species, and their function is clearly to prevent regurgitation of duodenal contents (Dardinski, 1935; Schwegler and Boyden, 1937; Kirk, 1944; Sterling, 1949; Cross, 1956; Di Dio and Boyden, 1962); Stensen's duct is protected in a similar fashion (Reitlinger, 1964). The occasional absence of these folds may increase the likelihood of pancreatitis (Echenberg and Brown, 1963).

The blind loop experiments in dogs suggested the possibility that pancreatitis might be produced by small pressure changes in the duodenum provided the duct papilla was damaged or incompetent (McCutcheon and Race, 1962). Experiments to support this argument have been described: removal of the mucosal valvules at the orifice of the pancreatic duct (after the method of Newman, Weinberg, Newman, and Northup, 1958) allows reflux of fluid up the duct at low physiological pressures (McCutcheon, 1964).

There is much clinical evidence to show that factors which interfere with the natural mechanism preventing reflux at the lower end of the pancreatic duct may lead to pancreatitis.

Sphincterotomy is a good example; many cases of pancreatitis following this operation have been reported (Blatherwick and Pattison, 1954; Thompson and Derrick, 1957; Telford, 1958).

Pancreatitis may follow the use of the long arm T tube of Cattell (Smith, Barker, and Kaplan, 1951; Blatherwick and Pattison, 1954; Thompson, Howard, and Vowles, 1957; Johnston, 1960; Ponka, Landrum, and Chaikof, 1961; Glenn and Frey, 1964). The long arm of the tube passing through the ampulla into the duodenum has two effects: it straightens the normal oblique line of the common bile duct and it acts as an internal splint preventing closure of ducts by sphincter and duodenal muscle contraction. Both of these procedures increase the possibility of regurgitation of duodenal contents into the pancreatic duct.

The association of pancreatitis with a gallstone impacted at the lower end of the common bile duct is explicable on the same basis, fixed dilatation of the duct allowing regurgitation of duodenal fluid.

Wright (1958) has reported a case of relapsing pancreatitis due to a pedunculated polyp inside the lower end of the common bile duct. Pancreatitis may occur when the pancreatic duct is invaded by an Ascaris (Schmieden and Sebening, 1928; Dragsted et al., 1934) or the papilla is dilated by granular material (Boss, 1955).

Reflux may occasionally be related to exaggerated physiological reactions. Bergh (1942a, b) showed that a fatty meal produced relaxation of the sphincter of Oddi and that this effect was not dependent on the presence of the gallbladder. Doubilet (1958a) has stated that a fatty meal following an attack of pancreatitis is a common cause of a severe recurrence. According to Mallet-Guy (1965) dystonia of the sphincter is a cause of pancreatitis; out of 150 cases in which dystonia was demonstrated by radiological and manometric methods, 133 were regarded as hypotonic.

Pancreatitis may be localized to that portion of the pancreas drained by the duct of Santorini (Opie, 
1910; Colp, 1930; Simkins, 1931; Dragstedt et al., 1934; Warren and Cattell, 1956). Opie and Meakin (1909) described such a case in an alcoholic patient and the only part of the pancreas which was normal was the small area drained by the duct of Wirsung. Reflux from the duodenum is the only mechanism capable of explaining the distribution of the lesion in these cases.

The role of proteolytic enzymes Over 50 years ago Polya produced acute pancreatitis by injecting small amounts of trypsin into the pancreatic duct. Rich and Duff confirmed this work and described specific vascular lesions which they found in all their cases of pancreatitis whether human or experimental; commercial trypsin injected subcutaneously in dogs produced the same vascular lesions. Keith, Barnes, and Denkewalter (1958) showed that acute pancreatitis could be produced regularly in dogs by injecting trypsin into the pancreatic interstitial tissue, but trypsinogen did not have the same effect. In contrast, some workers have doubted the importance of activation of enzymes in pancreatitis on the basis of experiments in which bile is injected forcibly into the pancreatic duct (Jenson, Imamoglu, Root, and Wangensteen, 1961; Beck, Pinter, Solymar, McKenna, and Ritchie, 1962); as bile does not activate trypsinogen these experiments could not be expected to prove anything. Although this experimental model is used commonly it is completely artificial and bears no relationship to the human disease. Other workers have been unable to produce pancreatitis using trypsin or enterokinase (Hansson, Lundh, and Stenram, 1961; Elmslie et al., 1966).

Ascitic fluid from patients with pancreatitis contains active trypsin as well as amylase and lipase (Elliott, Zollinger, Moore, and Ellison, 1955). Pancreatic juice from the inflamed pancreas has been found to contain a considerable amount of active proteolytic enzymes which tends to decrease as the patient recovers (Troll and Doubilet, 1951 ; Doubilet, 1958b). It has been claimed that serum proteolytic enzyme levels rise in pancreatitis while there is a concomitant fall in antifibrinolysin levels (Elliott et al., 1955; Nardi, 1958), but the demonstration of these enzymes in serum is difficult because of the presence of potent inhibitors (Dreiling, 1958).

There is no doubt that proteolytic enzymes are activated in acute haemorrhagic pancreatitis and are capable of causing the important vascular changes. McHardy and his associates (1963) consider that intrapancreatic conversion of trypsinogen to trypsin is the most important, if not the sole cause of pancreatitis'. The crucial question therefore is, what activates trypsinogen?

Grossman (1959) studied the problem of activa- tion of pancreatic enzymes and made severa限 important observations. Unactivated pancreatic juice contains a trace of active protease which is noE trypsin; neither bile, sodium cholate, inflammatoryexudate, streptokinase, nor an aqueous extract of human leucocytes produce any marked increase in the rate of appearance of active proteases wheris added to pancreatic juice; small amounts of crystal $\overrightarrow{0}$ line trypsin or enterokinase cause full activationwithin a few minutes. He concluded that 'these్లు results offer no support for the view that tissue juices, bile, or inflammatory exudates are capable of activating pancreatic protease'. Uncontaminate $\&_{0}$ pancreatic juice also contains a substantial amount of trypsin inhibitor (Haverback et al., 1960). \&ै

The activation of trypsinogen by enterokinase? is an enzymic reaction in which a peptide fraction is split off (Magee, 1962). Thus activation is a specific and complex process in which several inhibitory mechanisms are overcome; reflux of duodenal contents into the pancreatic duct is the only satisfactoryo explanation for this process when it occurs within the pancreas.

The action of pancreatic enzymes Several authors have questioned the role of trypsin, chymotrypsin, and other enzymes in producing pancreatic necrosiso because they do not digest healthy living epitheliaß cells (Hosie and Ziffren, 1956; Reid, Paulette $\vec{F}$ Challis, and Hinton, 1958; Hansson et al., $1961 \frac{3}{3}$ Matthews and McPhedran, 1963; Ferrini and Zito, 1961). This difficulty is overcome by the realization that pancreatitis is not a process of autodigestiono due to the action of enzymes on healthy acini Pancreatitis results from the action of a variety of enzymes on blood and blood vessels in the interstitial tissue leading to venous and capillary thrombosis, oedema, haemorrhage, and pancreatic necrosis. Pancreatic damage is due initially to vasculars deprivation; once this has occurred the damaged or necrotic tissue is susceptible to digestion (Mcㅡㅡ. Cutcheon and Race, 1962). The presence of blood N pigment may accelerate the destructive process (Nemir and Drabkin, 1956; Anderson, 1963).

Many authors since Rich and Duff (1936) havew stressed the importance of diffuse injury to smalk blood vessels in acute pancreatitis (Smyth 1940: Anderson and Bergan, 1961). Thal and his colleagues produced a fulminating haemorrhagic pancreatitis in rabbits, dogs, and goats by the Schwartzman phenomenon: bacterial toxin injected into the pancreatic duct at low pressures diffused rapidly? through intact ductal walls to the interstitial tissue. 0 Subsequent intravenous injection of the same toxire caused venous spasm and capillary stasis followed by vascular stagnation, oedema, necrosis, and haemoro rhage (Thal and Brackney, 1954; Thal and Molestina 
1955). In other experiments Thal, Tansathithaya, and Egner (1956) showed that the ability of certain organisms to cause pancreatic necrosis was related to their ability to produce extensive small vessel thromboses.

Safadi, Lazzarini, Pfeffer, Mixter, and Hinton (1961) consider that vascular damage is the 'final common pathway' in the genesis of pancreatitis; they produced haemorrhagic pancreatitis in dogs by injecting small polythene microspheres into the superior pancreatico-duodenal artery. Thal et al., (1957) studied 42 cases of fatal acute pancreatitis and concluded that capillary and venous thromboses were the common vascular lesions in human pancreatitis (see also Popper et al., 1948; Hardaway and McKay, 1959; Anderson, 1961).

There are many ways in which pancreatic enzymes may act on small blood vessels. Trypsin increases the permeability of pancreatic blood vessels and causes oedema (Dragstedt, 1943; Anderson and Lewis, 1965). Trypsin accelerates blood clotting (Ferguson, Wilson, Iatridis, Rierson, and Johnston, 1960). Small amounts of elastase added to plasma cause a marked shortening of the coagulation time (Marrama, Alberini, and Lapiccirella, 1960). Elastase and collagenase may attack elastic tissue and collagen fibres (Hosie and Ziffren, 1956; Blumenthal and Probstein, 1959). Recent work has shown that release of adenosine diphosphate (ADP) by cellular damage plays an important role in the initial stages of thrombosis (Gaarder, Jonsen, Laland, Hellem, and Owren, 1961). The possible action of pancreatic enzymes in liberating ADP and producing platelet thrombi requires further investigation.

The mechanism of action of pancreatic enzymes outlined here requires not only the presence of active free enzymes within the ductal system but their retention for a sufficient time to allow diffusion into the interstitial tissue. Doubilet, Poppel, and Mulholland (1957) have demonstrated the increased permeability of the pancreatic duct system in pancreatitis.

It is necessary to distinguish between enzymeinduced vascular damage and primary vascular disease; infarcts of the pancreas occur as a separate entity distinct from acute haemorrhagic pancreatitis (Braasch, 1958; McKay, Baggenstoss, and Wollaeger, 1958; Telford, 1958; Boyer and McKay, 1960). Pagel and Woolf (1948) reported a case in which aseptic necrosis of part of the pancreas occurred due to malignant hypertension with arterial thromboses: there was no evidence of fat necrosis or diffuse haemorrhagic pancreatitis. Hranilovich and Baggenstoss (1953) studied 100 necropsy cases of malignant hypertension; they found pancreatic infarcts in seven and focal parenchymal necrosis in 21 cases. Diffuse haemorrhagic pancreatitis or necrosis was not seen and they concluded that primary vascular lesions were not important in the production of haemorrhagic pancreatitis.

The evidence indicates that primary vascular lesions cause focal rather than diffuse necrosis because they do not produce general activation of pancreatic enzymes; they are in a different category from the diffuse vascular lesions which are secondary to the action of active enzymes. The contrast between the two serves to emphasize the primary role of activation of enzymes in the pathogenesis of pancreatitis.

The role of kinins Recent work has shown that free trypsin in the pancreas releases another proteolytic enzyme, kallikrein, from its inactive precursor and this in turn acts on kinin precursors to produce powerful vasoactive substances resembling bradykinin (Frey, 1963; Forell, 1963). Bradykinin causes vascular dilatation, increased capillary permeability, and extravasation of fluid. Blood from patients with pancreatitis and from animals with experimental pancreatitis has been found to contain similar vasoactive material (Hollenberg, Kobold, Pruett, and Thal, 1962; Thal, Kobold, and Hollenberg, 1963). These substances are thought to be responsible for the production of hypotension, dehydration, and shock in severe pancreatitis, and a large number of papers has been published on the use of proteolytic enzyme inhibitors in experimental and human pancreatitis (Forell, 1962; McCutcheon and Race, 1963; McHardy, Craighead, Balart, Cradic, and LaGrange, 1963; Nardi, 1963; Moshal, Marks, Bank, and Ford, 1963; Schutt, Wakim, Bartholomew, Cain, and Baggenstoss, 1965)

In relation to pathogenesis there is no evidence that kinins initiate pancreatitis although they are responsible for some of the clinical features; kinin production is secondary to the mechanism causing pancreatitis and is fired off by the presence of active trypsin. This process emphasizes further the basic importance of activation of proteolytic enzymes in the pathogenesis of pancreatitis.

Reflux from the duodenum into the pancreatic duct is occasionally observed during T-tube choledochograms (McCutcheon, 1964). In a number of cases the bile and pancreatic ducts enter the duodenum separately and the pancreatic duct is outlined by dye which has first entered the duodenum (Hicken and McAllister, 1952; Caroli et al., 1960). This has demonstrated the possibility of reflux in the presence of a relaxed sphincter and normal intraduodenal pressure.

There is a real association between peri-ampullary diverticula and pancreatitis (Herfort, Fric, and Keclík, 1963). Ogilvie (1941) described four cases 
of peri-Vaterine diverticulum, three of which were associated with pancreatic necrosis; in the fourth case obstruction of the pancreatic duct was present and the result was atrophy of the pancreas, not pancreatitis.

An analagous situation exists at the lower end of the ureter where the intravesical portion acts as a 'highly specialized valve that.... prevents reflux of bladder urine into the ureter' (Hutch, 1958). Vesico-ureteric reflux is a major aetiological factor in pyelonephritis and in hydroureter and hydronephrosis associated with upper motor neurone lesions of the spinal cord. It is an interesting fact that a small diverticulum in the region of the ureterovesical junction is often found in cases with reflux (Hutch, 1958). Here the conditions are remarkably similar to those described by Ogilvie in relation to pancreatitis and it is likely that his three cases were due to reflux from the duodenum.

\section{SUMMARY}

The evidence presented above suggests that reflux of duodenal contents into the pancreatic duct is the mechanism responsible for activation and release of pancreatic enzymes which diffuse across the duct wall into the interstitial tissue; there they cause a varying degree of vascular damage and obstruction leading to changes which vary in intensity from oedema and haemorrhage to frank infarction. If this view of pathogenesis is correct it should also explain the relationship between pancreatitis and known aetiological factors.

\section{ASSOCIATED AETIOLOGICAL FACTORS}

These may be divided into two groups: a major group consisting of cholelithiasis, alcoholism, postoperative pancreatitis, and idiopathic pancreatitis, and a minor group containing the less common causes, hyperparathyroidism, hyperlipaemia, trauma, pregnancy, drugs, and 'hereditary pancreatitis'. Only the major factors will be considered here as these constitute the majority of cases of pancreatitis.

IDIOPATHIC PANCREATITIS Every large series of unselected cases of pancreatitis contains a group in which no aetiological factors are discoverable; the size of this group varies from $16 \%$ to $50 \%$ of all cases (Blumenthal and Probstein, 1959; Howard and Jordan, 1960; Berman, Dunn, and Straehley, 1961 ; Child and Kahn, 1962; Herfort, 1963; Kaplan, Cotlar and Stagg, 1964; Mathiesen and Rasmussen, 1965; White, 1965). Joshi et al. (1957) reviewed their experience with 408 cases of acute pancreatitis over 25 years and concluded that the aetiology remained unexplained in about two-thirds. In a recent series of 324 case of acute pancreatitis, 129 were regarded as idiopathic (Trapnell and Anderson, 1967). The fact that this large group exists is worth stressing; often the impression is given that all the aetiological factors are known.

Most of these patients experience pancreatitis as a single isolated attack, for which reflux of duodenal contents would seem to be a reasonable explanation. Isolated or recurrent episodes of reflux occur at the sphincteric end of other tubes in the body and it is unlikely that the pancreatic duct would prove to be an exception. Considering the efficiency of the normal mechanism preventing reflux, isolated episodes are exactly what would be expected. It would also be expected that these episodes increased in frequency with increasing age.

PANCREATITIS AND CHOLELITHIASIS A definite relationship exists between biliary tract disease and pancreatitis because there is a high incidence of gallstones in patients with pancreatitis compared with a comparable group of patients without pancreatitis (Egdahl, 1907; Howard and Jordan, 1960; Dreiling et al., 1964). The nature of this relationship is obscure and the 'mechanism responsible for acute pancreatitis due to stones in the nonacutely inflamed gall bladder is difficult to understand' (Albo, Silen, and Goldman, 1963). There are three possibilities.

1 Cholelithiasis may cause pancreatitis The incidence of biliary tract disease in pancreatitis varies from $32 \%$ to $91 \%$ (Williams and Busch, 1907; Colp, 1930; Roberts, Baggenstoss, and Comfort, 1950; O'Brien and Thayer, 1955; Thal et al., 1957; Heffernon and Cassiet, 1958; Boyer and McKay, 1960; Berman et al., 1961; Herfort et al., 1963). According to Howard and Jordan (1960) cholecystectomy in this group tends to prevent a recurrence of acute pancreatitis (also Marks and Bank, 1963; Mathiesen and Rasmussen, 1965).

Joske (1955) confirmed the clinical association with cholelithiasis but in 14 of his cases pancreatitis persisted after removal of the stones and his figures provided 'no support for the theory that gallstones bear an aetiological relationship to pancreatitis'. Other workers have found that cholecystectomy does not necessarily prevent recurrences of pancreatitis (Probstein and Sachar, 1950; Pollock, 1958; Warren, 1961b; Glenn and Frey, 1964).

In only 118 out of 2,653 cases collected from the literature were stones present in the common bile duct (White, 1965). The strong evidence against the obstruction theory leaves one possible mechanism by which calculi in this position may cause pancreatitis; by dilating and splinting the lower end of 
the duct and allowing duodenal reflux. Gallstones cause pancreatitis therefore in only a small percentage of cases. There is no mechanism by which stones in the gallbladder can cause pancreatitis, so the bulk of cases really belong to the idiopathic group.

2 Pancreatitis may cause biliary tract disease Gambill, Comfort, and Baggenstoss (1948) analysed and compared two series of patients with chronic relapsing pancreatitis, 27 with and 29 without associated disease of the biliary tract. The clinical findings and course of pancreatitis were constant and similar in each group, suggesting to Gambill and his colleagues that disease of the biliary tract was secondary to disease of the pancreas. The occurrence of acute cholecystitis in patients with pancreatitis (Ivy and Gibbs, 1952) and the presence of active pancreatic enzymes in gallbladder bile in cholecystitis (Colp, Gerber, and Doubilet, 1936) support the idea that inflammation of the gallbladder is a complication of pancreatitis (McWhorter, 1932). Reid and Dorsey (1958) found that nine of 100 patients with pancreatitis had acalculous chronic cholecystitis and another 50 had gallstones; they suggested that pancreatitis causes compression of the end of the common bile duct, leading to stasis, biliary tract disease, and stone formation. Against this general hypothesis is the fact that biliary tract disease is much more common than pancreatitis.

A common underlying factor Both biliary and pancreatic disorders may be caused by a common underlying factor (Probstein, Gray, Sachar, and Rindskopf, 1949; Sinclair, 1959). This is the most likely possibility and is an exciting one because of its implications for the pathogenesis of gallstones. The aetiology of gallstones is as obscure as the aetiology of pancreatitis. If both conditions are due to a common factor and if reflux from the duodenum is the mechanism responsible for pancreatitis, then duodenal reflux must be a factor in the formation of gallstones. The following evidence may be cited in favour of this hypothesis.

Inflammation of the gallbladder and stone formation occur in man and dogs following the creation of a wide opening between the common bile duct and the intestine (Large, 1957). When the action of the sphincter of Oddi is eliminated some degree of ascending infection follows (Bergh, 1942b). Ekman and Sandblom (1962) studied 146 patients with an anastomosis between the biliary tract and the intestine and found symptoms of cholangitis in $24 \%$; they described four cases of cholangitis which proceeded to biliary cirrhosis and portal hypertension.

Sedlack, Hodgson, Butt, Stobie, and Judd (1961) reported 15 patients with gas in the biliary tree and none of these patients had an internal biliary fistula. Most of them had chronic cholecystitis with cholelithiasis. The authors concluded that an incompetent sphincter of Oddi can permit the reflux of gas into the biliary radicles. A similar case in which reflux of barium from duodenum to common bile duct was demonstrated has been reported by Cook, Hou, Ho, and McFadzean (1954). Other examples of biliary gas due to an incompetent sphincter of Oddi have been described by Pitman and Davies (1963).

In many eastern countries a high percentage of biliary calculi are parasitic in origin and associated with a variety of intestinal infections. Maki (1961) found parasitic elements (eggs or fragments of cuticle) at the centre of stones in more than $60 \%$ of cases in Japan. Recent chemical and bacteriological analysis of a series of gallstones in a western community showed a high percentage in which organisms, especially actinomyces, could be demonstrated (Rains, Barson, Crawford, and Shrewsbury, 1960). The authors regarded this as evidence for the theory of blood-borne infection causing a gallbladder lesion and stone formation. The organisms concerned are found normally in the oral-gastrointestinal tract and could provide a nidus for stone formation without causing cholecystitis if they gained direct access from the bowel via reflux of duodenal contents.

The common facetted multiple gallstones have a soft centre which often contains a protein substance resembling fibrin; Womack, Zeppa, and Irvin (1963) have suggested that these calculi originate from the fragmentation of a pultaceous mass. Reflux of duodenal contents containing protein and fibrous matter provides an explanation for the apparent 'seeding' of multiple gallstones of similar size at the one time. Acidification of bile causes precipitation of bile salts and cholesterol (Andrews, Schoenheimer, and Hrdina, 1932). The entry of acid chyme into the bile duct would also explain the occurrence of 'biliary mud'.

Jessen (1961) reported 30 Korean patients with biliary stones and 24 had calculi in the common bile duct without any stones in the gallbladder. Five patients had a dilated orifice at the ampulla of Vater and 'in no case was a stricture encountered in this region'.

The evidence outlined above indicates the importance of a competent emptying mechanism at the lower end of the bile and pancreatic ducts in preventing biliary tract disease and pancreatitis respectively. Reflux of duodenal contents is therefore an attractive hypothesis; it explains the relationship betwen pancreatitis and biliary tract disease, it suggests a mechanism for gallstone formation and it could be extended to cover problems relating to the post-cholecystectomy syndrome and the re- 
formation of stones in the biliary tree after adequate cholecystectomy and exploration of the common bile duct. The pancreatic duct with its mucosal folds is better protected than the common bile duct against duodenal reflux, and this would account for the much lower incidence of pancreatitis compared to gallbladder disease.

PANCREATITIS AND ALCOHOL Alcohol is particularly related to chronic relapsing pancreatitis (Probstein and Sachar, 1950; Jones and Smith, 1952; Cattell and Warren, 1953; Warren, 1959; Gambill, Baggenstoss, and Priestley, 1960; Bartlett and Nardi, 1960; Gross and Hallenbeck, 1960), and a feature of this group of cases is the relative absence of gallbladder disease (Clark, 1942; Edmonson et al., 1949; Waugh, 1959; Howard, 1960; Boyer and Mackay, 1960). The condition follows heavy drinking (usually including spirits) over a long period of time (Howard and Ehrlich, 1961; Marks and Bank, 1963; Herfort, 1963). Excess alcohol ingestion is by far the commonest cause of pancreatic lithiasis (Paulino-Netto, Dreiling, and Baronofsky, 1960).

Dreiling, Richman, and Fradkin (1952) suggested that alcohol caused pancreatitis by stimulating pancreatic secretion and by obstructing the pancreatic duct, the latter being due to spasm and oedema of the duct papilla. Menguy, Hallenbeck, Bollman, and Grindlay (1958) have shown that intraduodenal alcohol causes a rise in pancreatic intraductal pressure due to increased resistance of the sphincter mechanism (also Walton, Schapiro, Yeung, and Woodward, 1965). Warren and Veidenheimer (1962) believe that intrapancreatic obstruction of the major pancreatic ducts is responsible for recurrent attacks but Sarles and his associates (1965) have shown that stenosis of the duct of Wirsung is not present in the earlier stages of alcoholic pancreatitis. The strong arguments against the obstruction-hypersecretion theory are also against these views.

Myers and Keefer (1934) suggested that vomiting due to alcohol might cause regurgitation of duodenal contents and pancreatitis. They quoted some cases of pancreatic necrosis which followed vomiting due to general ether anaesthesia (Cracovaner, 1933). Mann and Giordano (1923) described the enormous rise in bile duct pressure produced by retching in animals; however, they felt that these mechanically induced changes could be ignored because the abdominal pressure must be the same throughout the peritoneal cavity. More recently Smith and Brizzee (1961), using a cine-radiographic technique in cats, described a unique type of prolonged contraction in the duodenum which occurred just before the act of vomiting. It is possible that these contractions could increase the intraduodenal pressure and provide a strong pressure gradient from the duodenum to the pancreatic and biliary ducts. This would not by itself cause regurgitation of duodenal contents in view of the normal protective mechanisms at the lower end of the pancreatic duct, and would not explain the majority of cases of chronic alcoholic pancreatitis. Sarles' group (1965) have emphasized the profound clinical, pathological and functional differences between relapsing acute pancreatitis and chronic alcoholic pancreatitis; the former tends to resolve completely and rarely progresses to the chronic stage. They consider that chronic alcoholic pancreatitis is a separate entity in which the initial lesion may be obstruction 'of the finer pancreatic ducts by a gel which seems to represent the precursor of calcification'. In their careful study they found no evidence of protein deficiency and they discuss other possible mechanisms, including the unmasking by alcohol of a genetic defect.

Many of the differences outlined by Sarles may be due simply to the fact that the aetiological agent is acting constantly in alcohol pancreatitis; the gland has no chance to recover and repeated inflammatory episodes lead to major duct obstruction with multiple calculi forming behind the obstruction. Expressed in another way, chronic calcific pancreatitis is almost always due to chronic alcoholism because we know of no other agent which acts so continuously. The mechanism of production may be the same, however, and brought about as follows.

Alcohol has a marked irritant action on mucosae and may cause oedema of the duodenum (Boba, Stein, Nakamura, and Powers, 1957). In a similar anatomical situation at the lower end of the ureter (Hutch, 1958) oedema of the bladder wall from infection causes reflux of urine up the ureter; reflux may also be induced experimentally by promoting mucosal oedema round the orifice of the ureter (Auer and Seager, 1937; Jacobsson and Sundin, 1963). It is possible that alcohol may act in a similar way at the ampulla of Vater allowing reflux of duodenal contents.

Damage to the mucosal valvules near the entrance of the pancreatic duct or to the nervous innervation of the papilla are other possibilities; an atonic sphincter mechanism increases the likelihood of duodenal reflux. Baker and Boles (1955) described three cases of pancreatitis in which the common bile duct was empty and dilated above a dilated atonic sphincter of Oddi and without any evidence of obstruction. Much more knowledge of the microanatomy of this region in alcoholic pancreatitis is needed before these ideas can be accepted or rejected. 
There is no doubt that all grades of severity of pancreatitis from acute to chronic may be caused by alcoholism (Marks and Bank, 1963) so that the spectrum of changes seen reflects the duration of action of the aetiological agent; the differences are in degree rather than in kind.

POSTOPERATIVE PANCREATITIS Postoperative pancreatitis occurs most commonly after gastric resections or biliary tract operations in which the common bile duct is explored, and the mortality rate is high (Boles, 1956; Howard and Jordan, 1960; Berman et al., 1961; Warren, 1961a). Direct surgical trauma to the pancreas and its ducts is generally considered to be the main cause (Burton, Eckman, and Haxo, 1957; Cattell and Braasch, 1961) although this traditional view has been challenged by Warren (1954) and others (Foster and Ziffren, 1962; McCutcheon and Race, 1962). Warren (1954) described seven cases of severe pancreatitis following gastrectomy which could not be attributed to surgical trauma and contrasted them with five cases in which the pancreatic duct was divided accidentally without causing pancreatitis.

Pancreatitis is much more common after a Polya gastrectomy than a Billroth I procedure (Wallensten, 1958; Saidi and Donaldson, 1963). The evidence that this is due to reflux from the duodenum has been described fully elsewhere (McCutcheon and Race, 1962). Many patients with the obstructed afferent loop syndrome and pancreatitis have been described (Perry, 1954; Noring, 1958; Blomquist, 1963; Dahlgren, 1964); sometimes the pancreas ap pears to be normal (Thal and Perry, 1956). Dreiling et al. (1960) recorded six cases of chronic duodenal obstruction with pancreatic inflammation; one was due to a carcinoma of the third part of the duodenum and at necropsy the pancreatic duct was dilated and opened into the duodenum separately from the common bile duct.

Chronic pancreatitis and pancreatic atrophy with steatorrhea have been reported after Polya gastrectomy (Herner and Ysander, 1960; Wilson, Loach, and Bogoch, 1962). This is of considerable interest because McCutcheon and Race (1962) found that in a few dogs with a closed duodenal loop pancreatitis did not occur due to early obstruction of the main pancreatic duct. The same complication must occasionally occur in man with an obstructed afferent loop and the long-term result would be pancreatic atrophy and steatorrhoea.

Reid and Dorsey (1958) described four patients who developed acute haemorrhagic pancreatitis after exploration of the common bile duct. Thompson et al. (1957) presented four similar cases and reviewed 75 cases of acute pancreatitis following biliary tract surgery, with a mortality of $77 \%$. At that time, 17 cases of pancreatitis following long arm T-tube drainage had been recorded with 16 deaths; later this number reached 24 with 22 deaths (Ponka et al., 1961). Cattell and Braasch (1961), however, had a similar incidence of postoperative pancreatitis $(0.9 \%)$ whether or not the long arm T-tube was used. Another considerable group of cases of pancreatitis occurs after sphincterotomy (Blatherwick and Pattison, 1954; Deucher, 1957; Walters, Tama, and Magisano, 1961; Warren, 1961a; Nugent, Warren, Jonasson, and de Paredes, 1964).

In all these cases involving instrumentation of the lower ends of the bile and pancreatic ducts it is likely that interference with the normal mechanism preventing reflux of duodenal contents is responsible for the development of pancreatitis.

There is some evidence that general anaesthesia relaxes the region of the ampulla of Vater. Caroli et al. (1960) have studied the function of the human biliary tract using cineradiography; they found that the best reflux of dye into the pancreatic duct occurred when general anaesthesia was used. Splanchnic anaesthesia and trinitrin also produce relaxation of the sphincter of Oddi (Urrutia and Lavezzo, 1951). By facilitating reflux from the duodenum these factors could explain the occurrence of pancreatitis after operations in other areas, notably transurethral resection of the prostate, where there has been no possibility of trauma to the pancreas (Renner, 1951; Frieden, 1956; Ferris, Lynn, Cain, and Baggenstoss, 1957; Foster and Ziffren, 1962; Levine, Gambill, and Greene, 1962; Frey and Beal, 1963).

\section{DISCUSSION}

A concept of pathogenesis has been presented which explains the pathological changes of pancreatitis and the relationship between these changes and known aetiological factors. When it is applied to the literature on the subject, the experimental evidence begins to make sense and a wide variety of case reports can be understood, particularly in relation to postoperative pancreatitis, sphincterotomy, long arm T-tubes, stones impacted at the lower end of the common bile duct, and periampullary diverticula. Two further examples show how the mechanism of duodenal reflux explains the occurrence of pancreatitis.

1 Sinclair (1959) described a case in which the main pancreatic duct was obstructed by a stone $6 \mathrm{~cm}$ from the tail; the duct behind the stone was greatly dilated but pancreatitis was confined to the other part of the gland with free drainage into 
the duodenum. The stone evidently protected the distal part of the gland from reflux.

2 Pancreatitis and calculous cholecystitis occurred together in five patients in whom the duct of Santorini was the principal pancreatic duct; the duct of Wirsung was absent (White, 1965).

\section{SUMMARY AND CONCLUSIONS}

Current theories about the pathogenesis of pancreatitis are untenable. Pancreatic duct obstruction and hypersecretion cannot explain the activation of pancreatic enzymes, the typical pathological changes or the manner in which various aetiological factors cause pancreatitis. The theory is contradicted by experimental and clinical evidence.

Active pancreatic enzymes are capable of producing all the characteristic features of haemorrhagic pancreatitis. Any theory which does not give priority to this fact must postulate some unknown agent capable of causing widespread vascular damage with secondary activation of enzymes. There is no evidence for such an agent. The central question in pathogenesis therefore is, What activates the enzymes?

Activation of pancreatic enzymes is a specific and complex process initiated by contact with duodenal secretions containing enterokinase.

Reflux of duodenal contents into the pancreatic duct is the only mechanism capable of explaining the activation of enzymes and the subsequent pathological changes. The enzymes diffuse into the interstitial tissue where they cause diffuse vascular damage. Oedema, haemorrhage, and necrosis of acinar tissue are initially due to ischaemia.

The experimental, pathological, and clinical evidence in favour of this hypothesis is presented. Experimental proof has been obtained that reflux from the duodenum in vivo causes haemorrhagic pancreatitis. Reflux has been demonstrated under various conditions: with increased intraduodenal pressure and a normal papilla of Vater; with normal intraduodenal pressure and a relaxed sphincter; with relatively low intraduodenal pressure and a damaged papilla of Vater.

The present hypothesis is compatible with known aetiological factors in pancreatitis: as an occasional event it accounts for the 'idiopathic' cases which form a considerable group in any large series; it explains postoperative pancreatitis, particularly where the normal mechanisms preventing reflux at the lower ends of the bile and pancreatic ducts have been interfered with; in alcoholic pancreatitis it is suggested that oedema of the papillary region or atony of the sphincter predispose to reflux; finally it explains the relationship between biliary tract disease and pancreatitis in a way which may lead to an understanding of the pathogenesis of gallstones.

\section{REFERENCES}

Albo, R., Silen, W., and Goldman, L. (1963). A critical clinical analysis of acute pancreatitis. Arch. Surg., 86, 1032-1038.

Anderson, M. C. (1961). Pancreatic hemorrhage. Relationship to necrotizing pancreatitis. Ibid., 83, 467-474.

(1963). Venous stasis in the transition of edematous pancreatitis to necrosis. J. Amer. med. Ass., 183, 534-537.

_- , and Bergan, J. J. (1961). Significance of vascular injury as a factor in the pathogenesis of pancreatitis. Ann. Surg., 154, 58-67.

- , and Lewis, M. B. (1965). Low-molecular-weight dextran therapy in experimental pancreatitis. J. Amer. med. Ass., 192, 398-400.

- Mehn, W. H., and Method, H. L. (1960). An evaluation of the common channel as a factor in pancreatic or biliary disease. Ann. Surg., 151, 379-390.

Andrews, E., Schoenheimer, R., and Hrdina, L. (1932). Etiology of gallstones. I. Chemical factors and the role of the gallbladder. Arch. Surg., 25, 796-810.

Archibald, E. (1919). The experimental production of pancreatitis in animals as the result of the resistance of the common duct sphincter. Surg. Gynec. Obstet., 28, 529-545.

Auer, J., and Seager, L. D. (1937). Experimental local bladder edema causing urine reflux into ureter and kidney. J. exp. Med., 66, 741-754.

Austen, W. G., and Baue, A. E. (1964). Catheter duodenostomy for the difficult duodenum. Ann. Surg., 160, 781-787.

Baker, J. W., and Boles, T. (1955). Observations pertaining to the place of surgery in acute pancreatitis. Gastroenterology, 28, 536-549.

Bartlett, M. K., and Nardi, G. L. (1960). Treatment of recurrent pancreatitis by transduodenal sphincterotomy and exploration of the pancreatic duct. New Engl. J. Med., 262, 643-648.

Beck, I. T., Pinter, E. J., Solymar, J., McKenna, R. D., and Ritchie, A. C. (1962). The role of pancreatic enzymes in the pathogenesis of acute pancreatitis. II. The fate of pancreatic proteolytic enzymes in the course of acute pancreatitis. Gastroenterology, 43, 60-70.

Becker, V., and Schaefer, J. (1957). Die Bedeutung des Speichel-odëms für die Pankreasatrophie nach experimenteller Gangunterbindung. Virchows Arch. path. Anat., 330, 243-266.

Berens, J. J., Baggenstoss, A. H., and Gray, H. K. (1954). Ductal changes in chronic pancreatitis. Arch. Surg., 68, 723-733.

Bergh, G. S. (1942a). The effect of food upon the sphincter of Oddi in human subjects. Amer. J. dig. Dis., 9, 40-43.

(1942b). The sphincter mechanism of the common bile duct in human subjects. Surgery, 11, 299-330.

Berman, L. G., Dunn, E., and Straehley, C. J., Jr. (1961). Survey of pancreatitis. Central New York Surgical Society. Gastroenterology, 40, 94-108.

Blatherwick, N. H., and Pattison, A. C. (1954). Acute pancreatitis complicating choledochal sphincterotomy. Amer. J. Surg., 88, 129-135.

Block, G. E., and Paloyan, E. (1963). Operations for pancreatitis. Surg. Clin. N. Amer., 43, 201-212.

Block, M. A., Wakim, K. G., and Baggenstoss, A. H. (1954). Experimental studies concerning factors in the pathogenesis of acute pancreatitis. Surg. Gynec. Obstet., 99, 83-90.

Blomquist, H. E. (1963). Acute obstruction of afferent loop following gastric resection a.m. Billroth II-Hofmeister. Acta chir. scand., 126, 92-102.

Blumenthal, H. T., and Probstein, J. G. (1959). Pancreatitis. Thomas, Springfield, Ill.

Boba, A., Stein, A. A., Nakamura, Y., and Powers, S. R., Jr. (1957). A study of the relationships between alcoholic intoxication, vomiting and acute haemorrhagic pancreatitis. Surg. Forum, 8, 251-254.

Bockus, H. L. (1965) Gastroenterology, vol. 3, 2nd ed. p. 999. Saunders, Philadelphia.

Boles, E. T., Jr. (1956). Postoperative pancreatitis. Arch. Surg., 73, $710-718$.

Boss, G. (1955). Acute on chronic pancreatitis in a boy of six. Med. Press, 234, 398-400.

Boyer, J. T., and MacKay, I. R. (1960). The aetiology, course and surgical aspects of pancreatitis. A review of 108 cases. Aust. N.Z. J. Surg., 30, 150-157. 
Braasch, J. W. (1958). The surgical anatomy of the liver and pancreas. Surg. Clin. N. Amer., 38, 747-758.

Brunschwig, A. (1949). Pancreatic physiology in the light of recent surgical experiences. Surg. Gynec. Obstet., 88, 266-267.

Burton, C. C., Eckman, W. G., Jr., and Haxo, J. (1957). Acute postgastrectomy pancreatitis. Amer. J. Surg., 94, 70-79.

Busch, H. (1959). Chemistry of Pancreatic Diseases. Thomas, Springfield, Ill.

Byrne, J. J., and Joison, J. (1964). Bacterial regurgitation in experimental pancreatitis. Amer. J. Surg., 107, 317-320.

- Reilly, P. S., and Toutounghi, F. M. (1964). Regurgitation in experimental pancreatitis. Ann. Surg., 159, 27-31.

Caroli, J., Porcher, P., Pequignot, G., and Delattre, M. (1960). Contribution of cineradiography to study of the function of the human biliary tract. Amer. J. dig. Dis., 5, 677-696.

Cattell, R. B., and Braasch, J. W. (1961). An evaluation of the long T-tube. Ann. Surg., 154, 252-254.

-, Colcock, B. P., and Pollack, J. L. (1957). Stenosis of the sphincter of Oddi. New Engl. J. Med., 256, 429-435.

- , and Warren, K. W. (1953). Surgery of the Pancreas. Saunders, Philadelphia.

Child, C. G., III, and Kahn, D. R. (1962). Current status of therapy of pancreatitis. J. Amer. med. Ass., 179, 363-367.

Clark, E. (1942). Pancreatitis in acute and chronic alcoholism. Amer. J. dig. Dis., 9, 428-431.

Colp, R. (1930). Acute pancreatitis. Ann. Surg., 91, 392-400.

- Gerber, I. E., and Doubilet, H. (1936). Acute cholecystitis associated with pancreatic reflux. Ibid., 103, 67-76.

Comfort, M. W., Gambill, E. E., and Baggenstoss, A. H. (1946) Chronic relapsing pancreatitis: a study of 29 cases without associated disease of the biliary or gastrointestinal tract. Gastroenterology, 6, 239-285 and 376-408.

Cook, J., Hou, P. C., Ho, H. C., and McFadzean, A. J. S. (1954). Recurrent pyogenic cholangitis. Brit. J. Surg., 42, 188-203.

Cracovaner, D. J. (1933). Acute pancreatic necrosis occurring during general anaesthesia with report of 3 cases. U.S. nav. med. Bull., 31, 268-276.

Cross, K. R. (1956). Accessory pancreatic ducts: special reference to the intrapancreatic portion of the common duct. Arch. Path., 61, 434-440.

Dahlgren, S. (1964). The afferent loop syndrome. Acta chir. scand., suppl. 327.

Dardinski, V. J. (1935). The anatomy of the major duodenal papilla of man, with special reference to its musculature. J. Anat. (Lond.), 69, 469-478.

Deucher, F. (1957). Pancreatite mortelle après drainage transpapillaire du canal cholédoque. Gastroenerologia (Basel), 88, 311-321.

Di Dio, L. J. A., and Boyden, E. A. (1962). The choledochoduodenal junction of the horse- a study of the musculature around the ends of the bile and pancreatic ducts in a species without a gall bladder. Anat. Rec., 143, 61-69.

Doubilet, H. (1958a). The physiological basis for the surgical management of acute and chronic pancreatitis. Surg. Clin. N. Amer., 38, 505-520.

(1958b). Physiology of the human panereas. Surg. Gynec. Obstet., 107, 97-98.

- , Poppel, M. H., and Mulholland, J. H. (1957). Pancreatography: indications and observations. J. Amer. med. Ass., 163, 10271030.

Dragstedt, C. A. (1943). The digestion of living tissues by proteolytic enzymes. Science, 98, 131-132.

—-, Haymond, H. E., and Ellis, J. C. (1934). Pathogenesis of acute pancreatitis (acute pancreatic necrosis). Arch. Surg., 28, 232-291.

Dreiling, D. A. (1958). Experimental pancreatitis-a critical review. J. Mt Sinai Hosp., 25, 128-136.

- (1961). The pathological physiology of pancreatic inflammation. Current status 1960. J. Amer. med. Ass., 175, 183-186.

- and Janowitz, H. D. (1962). The measurement of pancreatic secretory function In Ciba Foundation Symposium on The Exocrine Pancreas, Normal and Abnormal Functions, edited by A. V. S. de Reuck and M. P. Cameron, pp. 225-258. Churchill, London.

, and Perrier, C. V. (1964). Pancreatic Inflammatory Disease. Harper and Row, New York.

—, Kirschner, P. A., and Nemser, H. (1960). Chronic duodenal obstruction: a mechano-vascular etiology of pancreatitis. J. Report of 6 cases illustrating this clinical variety. Amer. J. dig. Dis., 5, 991-1005.
Richman, A., and Fradkin, N. F. (1952). The role of alcohol in the etiology of pancreatitis: a study of the effect of intravenous ethyl alcohol on the external secretion of the pancreas. Gastroenterology, 20, 636-646.

Dunphy, J. E., Brooks, J. R., and Achroyd, F. (1953). Acute postoperative pancreatitis. New Engl. J. Med., 248, 445-451.

DuVal, M. K., Jr (1954). Caudal pancreatico-jejunostomy for chronic relapsing pancreatitis. Ann. Surg., 140, 775-785.

Echenberg, R. J. and Brown, J. O. (1963). A morphologic approach to the problem of reflux pancreatitis. J. int. Coll. Surg., 40, 319-331.

Edmondson, H. A., Bullock, W. K., and Mehl, J. W. (1949). Chronic pancreatitis and lithiasis. I. A clinicopathologic study of 62 cases of chronic pancreatitis. Amer. J. Path., 25, 1227-1247.

Egdahl, A. (1907). A review of one hundred and five reported cases of acute pancreatitis with special reference to etiology; with report of two cases. Bull. Johns Hopk. Hosp., 18, 130-136.

Egdahl, R. H. (1964). Chronic alcoholic pancreatitis: a surgical disease? Surgery, 55, 604-606.

Ekman, C. A., and Sandblom, P. (1962). Bilio-intestinal anastomosis as a cause of liver cirrhosis with portal hypertension. Acta chir. scand., 123, 383-388.

Elliott, D. W., Williams, R. D., and Zollinger, R. M. (1957). Alterations in the pancreatic resistance to bile in the pathogenesis of acute pancreatitis. Ann. Surg., 146, 669-682.

_- Zollinger, R. M., Moore, R., and Ellison, E. H. (1955). The use of human serum albumin in the management of acute pancreatitis. Gastroenterology, 28, 563-587.

Elmslie, R., and White, T. T. (1965). The treatment of chronic recurrent pancreatitis by pancreatic surgery. Med. J. Aust., 1, 506-508.

- - , and Magee, D. F. (1966). The significance of reflux of trypsin and bile in the pathogenesis of human pancreatitis. Brit. J. Surg., 53, 809-816.

Eve, F. (1915). Acute haemorrhagic pancreatitis; with remarks on the etiology of chronic pancreatitis. Lancet, 1, 1-10.

Ferguson, J. H., Wilson, E. G., Iatridis, S. G., Rierson, H. A., and Johnston, B. R. (1960). Enzymes and blood clotting. I. Trypsin as an accessory factor. J. clin. Invest., 39, 1942-1952.

Ferrini, U., and Zito, R. (1961). Action of trypsin on Bence-Jones protein derivatives. Nature (Lond)., 189, 485.

Ferris, D. O., Lynn, T. E., Cain, J. C., and Baggenstoss, A. H. (1957). Fatal postoperative pancreatitis. Ann. Surg., 146, 263-273.

Forell, M. M. (1962). Activation and inhibition of pancreatic proteolytic enzymes and their clinical significance. Germ. med. Mth., 7, 37-40.

- (1963). Therapy with kallikrein and protease inhibitors. Ann. N.Y. Acad. Sci., 104, 368-375.

Foster, P. D., and Ziffren, S. E. (1962). Severe acute pancreatitis. Arch. Surg., 85, 252-259.

Frey, C. F., and Beal, J. M. (1963). Pancreatitis as a complication of operation. Ibid., 87, 1053-1058.

Frey, E. K. (1963). Opening remarks on kallikreins. Ann. N.Y. Acad. Sci., 104, 90.

Frieden, J. H. (1956). Postoperative acute pancreatitis. Surg. Gynec. Obstet., 102, 139-144.

Gaarder, A., Jonsen, J., Laland, S., Hellem, A., and Owren, P. A (1961). Adenosine diphosphate in red cells as a factor in the adhesiveness of human blood platelets. Nature (Lond.), 192, 531-532.

Gambill, E. E., Baggenstoss, A. H., and Priestley, J. T. (1960). Chronic relapsing pancreatitis: fate of fifty-six patients first encountered in the years 1939 to 1943, inclusive. Gastroenterology, 39,

404-411.
- Comfort, M.W., and Baggestoss, A. H. (1948). Chronic relapsing pancreatitis: an analysis of 27 cases associated with disease of the biliary tract. Ibid., 11, 1-33.

Glenn, F., and Frey, C. (1964). Re-evaluation of the treatment of pancreatitis associated with biliary tract disease. Ann. Surg. 160, 723-736.

Goldstein, F., Wirts, C. W., Cozzolino, H. J., and Menduke, H. (1964). Secretin tests of pancreatic biliary tract disease. Arch. intern. Med., 114, 124-131.

Greenfield, H., Siegel, L. H., and De Francis, N. (1955). Attempted visualization of the pancreatic ducts by ampullary reflux Gastroenterology, 29, 280-284.

Gross, J. B., and Hallenbeck, G. A. (1960). Chronic relapsing pancreatitis despite achlorhydria. Ibid., 38, 919-925.

Grossman, M. I. (1959). Experimental pancreatitis: recent contributions. J. Amer. med. Ass., 169, 1567-1570. 
Hansson, K., Lundh, G., and Stenram, U. (1961). Morphological and secretory studies in experimentally induced pancreatitis in rats. Acta chir. scand., 121, 274-283.

Hardaway, R. M., and McKay, D. G. (1959). Production of acute haemorrhagic pancreatitis in dogs by means of an episode of intravascular clotting in the pancreas. Surgery, 45, 557-561.

Haverback, B. J., Dyce, B. Bundy, H., and Edmondson, H. A. (1960). Trypsin, trypsinogen and trypsin inhibitor in human pancreatic juice. Amer. J. Med., 29, 424-433.

Heffernon, E. W., and Cassiet, A. C. (1958). A survey of acute hemorrhagic pancreatitis. Gastroenterology, 35, 251-255.

Herfort, K. (1963). Etiology of chronic relapsing pancreatitis. Analysis of 151 cases. Gastroenterologia (Basel), 100, 149-156.

—, Fric, P., and Keclik, M. (1963). Chronic relapsing pancreatitis. I. Clinical manifestations of acute attacks and possible aetiological factors. Acta med. scand., 174, 329-339.

Hermann, R. E., and Knowles, R. C. (1965). Lethal factors and response to therapy in experimental bile-reflux pancreatitis. Ann. Surg., 161, 456-465.

Herner, B., and Ysander, L. (1960). Chronic pancreatic insufficiency after Billroth II operations. Acta med. scand., 166, 395-398.

Hess, W. (1965). Surgery of the Biliary Passages and the Pancreas. Translated by H. Lamm. p. 93. Van Nostrand, Princeton, New Jersey.

Hicken, N. F., and McAllister, A. J. (1952). Is the reflux of bile into the pancreatic ducts a normal or abnormal physiologic process? Amer. J. Surg., 83, 781-786.

Hinshaw, D. B., Carter, R., Baker, H. W., and Wise, R. A. (1960). Postgastrectomy afferent loop obstruction simulating acute pancreatitis. Ann. Surg., 151, 600-604.

Hollenberg, M., Kobold, E. E., Pruett, R., and Thal, A. P. (1962) Occurrence of circulating vasoactive substances in human and experimental pancreatitis. Surg. Forum, 13, 302-304.

Hosie, R. T., and Ziffren, S. E. (1956). The relationship of collagenase to pancreatitis. Surgery, 40, 185-190.

Howard, J. M. (1960). Surgical management of acute pancreatitis. J. Amer. med. Ass., 174, 1687-1689.

-, and Ehrlich, E. W. (1961). A clinical study of alcoholic pancreatitis. Surg. Gynec. Obstet., 113, 167-173.

- , and Jordan, G. L. (1960). Surgical Diseases of the Pancreas. Lippincott, Philadelphia.

Hranilovich, G. T., and Baggenstoss, A. H. (1953). Lesions of the pancreas in malignant hypertension. Arch. Path., 55, 443-456.

Hutch, J. A. (1958). The Ureterovesical Junction. University of California Press, Berkeley.

Ivy, A. C., and Gibbs, G. E. (1952). Pancreatitis; a review. Surgery, $31,614-642$.

Jacobsson, B., and Sundin, T. (1963). Vesico-ureteral reflux following slitting of the urethral orifice. Acta chir. scand., 125, 261-266.

Janowitz, H. D., and Dreiling, D. A. (1959). Is there pancreatic ductal obstruction in chronic pancreatitis? In Proceedings of the World Congress of Gastroenterology, 1958, vol. II. pp. 12181222. Williams and Wilkins, Baltimore.

Jenson, C. B., Imamoglu, K., Root, H. D., and Wangensteen, O. H. (1961). The effect of hypothermia on experimentally induced hemorrhagic pancreatic necrosis. Gastroenterology, 40, 532-535.

Jessen, C. (1961). Gall stones restricted to the biliary ducts. Acta chir. scand., suppl. 283, 242-246.

Johnson, T. A., and Kalser, M. H. (1959). The pancreas. Contributions of clinical interest. Gastroenterology, 36, 295-332.

Johnston, J. H., Jr. (1960). Acute postoperative pancreatitis. Amer. Surg., 26, 595-600.

Jones, S. A., and Smith, L. L. (1952). Transduodenal sphincteroplasty for recurrent pancreatitis. Ann. Surg., 136, 937-947.

-, and Gregory, G. (1958). Sphincteroplasty for recurrent pancreatitis. A second report. Ibid., 147, 180-190.

Joshi, R. A., Probstein, J. G., and Blumenthal, H. T. (1957). A survey of experiences with three hundred clinical and one hundred and eighty autopsy cases of acute pancreatitis. Amer. Surg., 23, 34-42.

Joske, R. A. (1955). Aetiological factors in the pancreatitis syndrome. Brit. med. J., 2, 1477-1481.

Judd, E. S. (1921). Relation of the liver and the pancreas to infection of the gallbladder. J. Amer. med. Ass., 77, 197-201.

Kaplan, M. H., Cotlar, A. M., and Stagg, S. J. (1964). Acute pancreatitis. Six years survey with evaluation of steroid therapy. Amer. J. Surg., 108, 24-30.

Keith, L. M., Jr., Barnes, J. E., and Denkewalter, F. R. (1958), Experimental study of interstitial injection of trypsin and trypsinogen into the pancreas. Arch. Surg., 77, 416-420.
Kirk, J. (1944). Observations on the histology of the choledochoduodenal junction and papilla duodeni, with particular reference to the ampulla of Vater and sphincter of Oddi. J. Anat., (Lond.), 78, 118-120.

Large, A. M. (1957). Regurgitation cholecystitis and cholelithiasis. Ann. Surg., 146, 607-618.

Levine, S. R., Gambill, E. E., and Greene, L. F. (1962) Acute pancreatitis following transurethral prostatic resection: report of six cases. J. Urol. (Baltimore), 88, 657-663.

Lium, R., and Maddock, S. (1948). Etiology of acute pancreatitis. Surgery, 24, 593-604.

Longmire, W. P., Jr., and Wallner, M. A. (1956). Pancreatitis occurring in heterotopic pancreatic tissue. Ibid., 40, 412-418.

McCutcheon, A. D. (1962). Aetiological factors in pancreatitis Lancet, 1, 710-712.

- (1964). Reflux of duodenal contents in the pathogenesis of pancreatitis. Gut, 5, 260-265.

- - and Race, D. (1962). Experimental pancreatitis: a possible etiology of postoperative pancreatitis. Ann. Surg., 155, 523-531. - (1963). Experimental pancreatitis: use of a new antiproteolytic substance, Trasylol. Ibid., 158, 233-239.

McDonough, F. E., and Wise, R. E. (1955). Limitations to the clinical application of intravenous cholangiography in determining disease of the bile ducts after cholecystectomy. Gastroenterology, 29, 771-788.

McHardy, G., Craighead, C. C., Balart, L., Cradic, H., and LaGrange, C. (1963). Pancreatitis: intrapancreatic proteolytic trypsin activity. J. Amer. med. Ass., 183, 527-529.

McKay, J. W., Baggenstoss, A. H., and Wollaeger, E. E. (1958). Infarcts of the pancreas. Gastroenterology, 35, 256-264.

McWhorter, G. L. (1932). Acute pancreatitis. Report of sixty-four cases. Arch. Surg., 25, 958-990.

Magee, D. F. (1962). Gastro-intestinal Physiology, p. 90. Thomas, Springfield, IIl.

Maki, T. (1961). Cholelithiasis in the Japanese. Arch. Surg., 82, 599-612.

Mallet-Guy, P. (1965). Treatment of chronic pancreatitis. Amer. J. Surg., 109, 756-759.

Mann, F. C., and Giordano, A. S. (1923). The bile factor in pancreatitis. Arch. Surg., 6, 1-30.

Marks, I. N., and Bank, S. (1963). The aetiology, clinical features and diagnosis of pancreatitis in the South Western Cape. A review of 243 cases. S. Afr. med. J., 37, 1039-1053.

Marrama, P., Alberini, B., and Lapiccirella, R. (1960). Effeti in vitro delt elastasi pancreatyca sui processi emocoagulativi. Acto Vitamin (Milano), 14, 115-120. Abstract in Chem. Abstr. (1961), 55, 14623e.

Matthews, R. E., and McPhedran, N. T. (1963). Failure of activated trypsin to cause experimental acute haemorrhagic pancreatitis. Canad. J. Surg., 6, 102-105.

Mathieson, F. R., and Rasmussen, E. (1965). Sequels of acute pancreatitis. A follow-up study of 162 patients. Acta chir. scand., $129,410-416$

Menguy, R. B., Hallenbeck, G. A., Bollman, J. L., and Grindlay, J. H. (1958). Intraductal pressures and sphincteric resistance in canine pancreatic and biliary ducts after various stimuli. Surg. Gynec. Obstet., 106, 306-320.

Moshal, M. G., Marks, I. N., Bank, S., and Ford, D. A. (1963). A trial of 'Trasylol' in the treatment of acute pancreatitis. S. Afr. med. J., 37, 1072-1077.

Myers, W. K., and Keefer, C. S. (1934). Acute pancreatic necrosis in acute and chronic alcoholism. New Engl. J. Med., 210, 1376-1380.

Nance, F. C. and Cain, J. L. (1967). Hemorrhagic pancreatitis in germ dogs. Surg. Forum, 18, 365-367.

Nardi, G. L. (1958). Serum trypsin determination in pancreatic disease. J. Lab. clin. Med., 52, 66-69.

(1963). Current concepts in therapy: pancreatitis. New Engl. J. Med., 268, 1065-1067.

Nemir, P., Jr., and Drabkin, D. L. (1956). The pathogenesis of acute necrotizing hemorrhagic pancreatitis; an experimental study. Surgery, 40, 171-184.

Newman, H. F., Weinberg, S. B., Newman, E. B., and Northup, J. D. (1958). The papilla of Vater and distal portions of the common bile duct and duct of Wirsung. Surg. Gynec. Obstet., 106, 687-694.

Nordman, O. (1913). Experimente und klinische Betrachtungen uber die Zusammenhänge zwischen acuter Pankreatitis und Erkrankungen der Gallenblase. Langenbecks Arch. klin. Chir., 102, 66-120. 
Noring, O. (1958). The afferent loop syndrome elucidated by three cases. Acta chir. scand., 115, 276-283.

Nugent, F. W., Warren, K. W., Jonasson, H. and de Paredes, G. G. (1964). Early experience with Trayslol in the treatment of acute pancreatitis. Sth. med. J. (Bgham, Ala.), 57, 1317-1321.

O'Brien, J. J., and Thayer, T. R. (1955). Pancreatitis. Observations on 131 patients. New Engl. J. Med., 253, 355-360.

Ogilvie, R. F. (1941). Duodenal diverticula and their complications with particular reference to acute pancreatic necrosis. Brit. $J$. Surg., 28, 362-379.

Opie, E. L. (1901a). The relation of cholelithiasis to disease of the pancreas and to fat necrosis. Bull Johns Hopk. Hosp., 12, 19-21.

- (1901b). The etiology of acute hemorrhagic pancreatitis. Ibid., 12, 182-188.

- (1910). Disease of the Pancreas, its Cause and Nature, 2nd ed. Lippincott, Philadelphia.

- and Meakin, J. C. (1909). Data concerning the etiology and pathology of hemorrhagic necrosis of the pancreas (acute hemorrhagic pancreatitis). J. exp. Med., 11, 561-578.

Pagel, W., and Woolf, A. L. (1948). Aseptic necrosis of pancreas due to arterial thrombosis in malignant hypertension. Brit. med. J., 1, 442-443.

Paulino-Netto, A., and Dreiling, D. A. (1960). Chronic duodenal obstruction: a mechano-vascular etiology of pancreatitis. II. Experimental observations. Amer. J. dig. Dis., 5, 1006-1018. , and Baronofsky, I. D. (1960). The relationship between pancreatic calcification and cancer of the pancreas. Ann. Surg., 151, 530-537.

- , and Paulino, F. (1963). Pancreatic ductal reflux. Amer. J. dig. Dis., 8, 666-672.

Perman, E. (1935). Surgical treatment of gastric and duodenal ulcer. Acta chir. scand., suppl. 38, 142.

Perry, T., Jr (1954). Post-gastrectomy proximal jejunal loop obstruction simulating acute pancreatitis. Ann. Surg., 140, 119-121.

Pfeffer, R. B., Stasior, O., and Hinton, J. W. (1957). The clinical picture of the sequential development of acute hemorrhagic pancreatitis in the dog. Surg. Forum, 8, 248-251.

Pitman, R. G., and Davies, A. (1963). The clinical and radiological features of spontaneous internal biliary fistulae. Brit. J. Surg. 50, 414-425.

Pollock, A. V. (1958). Pancreatography in the diagnosis of chronic relapsing pancreatitis. Surg. Gynec. Obstet., 107, 765-770.

Ponka, J. L., Landrum, S. E., and Chaikof, L. (1961). Acute pancreatitis in the postoperative patient. Arch Surg., 83, 475-490.

Popper, H. L., and Necheles, H. (1942). Edema of the pancreas. Surg. Gynec. Obstet., 74, 123-124.

- - _ , and Russell, K. C. (1948). Transition of pancreatic edema into pancreatic necrosis. Ibid., 87, 79-82.

Powers, S. R., Jr., Brown, H. H., and Stein, A. (1955). The pathogenesis of acute and chronic pancreatitis. Ann. Surg., 142, 690-697.

Probstein, J. G., Gray, S. H., Sachar, L. A., and Rindskopf, W. J. (1949). Surgical implications of acute pancreatitis. Arch. Surg., $59,189-198$.

--, and Sachar, L. A. (1950). Acute pancreatitis: questions and answers. Surg. Clin. N. Amer., 30, 1457-1463.

Radakovich, M., Pearse, H. E., and Strain, W. H. (1952). Study of the etiology of acute pancreatitis. Surg. Gynec. Obstet., 94, 749-754.

Rains, A. J. H., Barson, G. J., Crawford, N., and Shrewsbury, J. F. D. (1960). A chemical and bacteriological study of gallstones. The presence of an actinomycete. Lancet, 2, 614-618.

Reid, L. C., Paulette, R. E., Challis, T. W., and Hinton, J. W. (1958). The mechanism of the pathogenesis of pancreatic necrosis and the therapeutic effect of propylthiouracil. Surgery, 43, 538-549.

Reid, S. E., and Dorsey, J. M. (1958). Fate of the patient with acute pancreatitis. Arch. Surg., 76, 895-897.

Reitlinger, A. (1964). Parotisverändervngen bei Musitern. Mschr. Ohrenheil., 98, 101-103. Also Wld Wide Abstr. gen. Med., (1965), 8, 2-3.

Renner, W. F., (1951). Postoperative acute pancreatitis and lower nephron syndrome. J. Amer. med. Ass., 147, 1654-1655.

Rich, A. R., and Duff, G. L. (1936). Experimental and pathological studies on the pathogenesis of acute haemorrhagic pancreatitis. Bull. Jokns Hopk. Hosp., 58, 212-259.

Roberts, N. J., Baggenstoss, A. H., and Comfort, M. W. (1950). Acute pancreatic necrosis. A cliniopathologic study. Amer. J. clin. Path., 20, 742-764.
Safadi, D., Lazzarini, A. A., Jr, Pfeffer, R. B., Mixter, G., Jr, and Hinton, J. W. (1961). The vascular basis for hemorrhagic pancreatitis in dogs. Hourly observations and results of calibrated microsphere injections. Bull. N.Y. Acad. Med., 37, 69-72.

Saidi, F., and Donaldson, G. A. (1963). Acute pancreatitis following distal gastrectomy for benign ulcer. Amer. J. Surg., 105, 87-92.

Sarles, H., Sarles, J. C., Camatte, R., Muratore, R., Gaini, M., Guien, C., Pastor, J., and Le Roy, F. (1965). Observations on 205 confirmed cases of acute pancreatitis, recurring pancreatitis and chronic pancreatitis. Gut, 6, 545-559.

Schmieden, V., and Sebening, W. (1928). Surgery of the pancreas with special consideration of acute pancreatic necrosis. Surg. Gynec. Obstet., 46, 735-751.

Schwegler, R. A., Jr, and Boyden, E. A. (1937). The development of the pars intestinalis of the common bile duct in the human fetus, with special reference to the origin of the ampulla of Vater and sphincter of Oddi. I .The involution of the ampulla. Anat. Rec., 67, 441-467.

Schutt, A. J., Wakim, K. G., Bartholomew, L. G., Cain, J. C., and Baggenstoss, A. H. (1965). Acute experimental pancreatitis. Role of proteolytic enzyme inhibitor in treatment. J. Amer. med. Ass., 191, 905-909.

Sedlack, R. E., Hodgson, J. R., Butt, H. R., Stobie, G. H. C., and Judd, E. S. (1961). Gas in the biliary tract. Clinical and experimental observations. Gastroenterology, 41, 551-556.

Shader, A. E., and Paxton, J. R. (1966). Fatal pancreatitis. Amer. J. Surg., 111, 369-373.

Silen, W., Baldwin, J., and Goldman, L. (1963). Treatment of chronic pancreatitis by longitudinal pancreatico-jejunostomy. Ibid., $106,243-258$.

Simkins, S. (1931). Variations in the pancreatic ducts and the minor duodenal papilla. Amer. J. med. Sci., 182, 626-639.

Sinclair, I. S. R. (1959). Acute pancreatitis: primary and postoperative. J. roy. Coll. Surg. Edinb., 5, 57-76.

Smith, C. C., and Brizzee, K. R. (1961). Cineradiographic analysis of vomiting in the cat. I. Lower esophagus, stomach and small intestine. Gastroenterology, 40, 654-664.

Smith, S. W., Barker, W. F., and Kaplan, L. (1951). Acute pancreatitis following transampullary biliary drainage. Surgery, 30, 695-700.

Smyth, C. J. (1940). Etiology of acute hemorrhagic pancreatitis with special reference to the vascular factors. An analysis of autopsies and an experimental investigation. Arch. Path., 30, 651-669.

Sterling, J. A. (1949). The termination of the common bile duct. Rev. Gastroent., 16, 821-845.

Strack, R., Dreizin, D. H., Ketyer, S., and Lazaro, E. J. (1967) Duodenal reflux in the genesis of acute pancreatitis. Canad. J. Surg., 10, 68-74.

Telford, D. (1958). Postoperative acute pancreatitis. Ibid., 2, 22-28.

Thal, A., and Brackney, E. (1954). Acute hemorrhagic pancreatic necrosis produced experimentally by local Shwartzman reaction. J. Amer. med. Ass., 155, 569-574.

-, Goott, B., and Margulis, A. R. (1959). Sites of pancreatic duct obstruction in chronic pancreatitis. Ann. Surg., 150, 49-56. Kobold, E. E., and Hollenberg, M. J. (1963). The release of vasoactive substances in acute pancreatitis. Amer. J. Surg., $105,708-713$.

_, and Molestina, J. E. (1955). Studies on pancreatitis. III. Fulminating hemorrhagic pancreatic necrosis produced by means of staphylococcal toxin. Arch. Path., 60, 212-220.

- and Perry, J. F., Jr., (1956). A further case of afferent loop obstruction simulating acute pancreatitis. Ann. Surg., 143, 266-268.

- - , and Egner, W. (1957). A clinical and morphologic study of forty-two cases of fatal acute pancreatitis. Surg. Gynec. Obstet., 105, 191-202.

—, Tansathithaya, P., and Egner, W. (1956). An experimental study of bacterial pancreatitis. Ibid., 103, 459-468.

Thompson, J. A., and Derrick, J. R. (1957). The diagnosis and management of acute pancreatitis. Amer. J. Surg., 94, 558-563.

, Howard, J. M., and Vowles, K. D. J. (1957). Acute pancreatitis following choledochotomy. Surg. Gynec. Obstet., 105, 706-710.

Trapnell, J. E., and Anderson, M. C. (1967). Role of early laparotomy in acute pancreatitis. Ann. Surg., 165, 49-55.

Troll, W., and Doubilet, H. (1951). The determination of proteolytic enzymes and proenzymes in human pancreatic juice. Gastroenterology, 19, 326-330.

Urrutia, J. M., and Lavezzo, P. (1951). Pharmaco-cholangiography in diagnosis of odditis. Radiology, 56, 80-83. 
Wainwright, C. W. (1951). Intrapancreatic obstruction. New Engl. J. Med., 244, 161-170.

Wallensten, S. (1958). Acute pancreatitis and hyperdiastasuria after partial gastrectomy. Acta chir. scand., 115, 182-188.

Walters, W., Tama, L., and Magisano, J. (1961). Acute hemorrhagic pancreatitis and necrosis associated with choledochal sphincterotomy. Surg. Clin. N. Amer., 4i, 979-990.

Walton, B. E., Schapiro, H., Yeung, T., and Woodward, E. R. (1965). Effect of alcohol on pancreatic duct pressure. Amer. Surg. 31, 142-144.

Wang, C. I., Strauss, L., and Adlersberg, D. (1958). Experimental pancreatitis and plasma lipids. Gastroenterology, 35, 465-472.

- , Wang, K. J., and Grossman, M. I. (1950). Effects of ligation of the pancreatic duct upon the action of secretin and pancreozymin in rabbits with a correlated histological study. Amer. J. Physiol., 160, 115-121.

Warren, K. W. (1954). Pancreatic consideration in gastric surgery. J. Amer. med. Ass., 154, 803-810.

- 1959. Pathologic considerations as a guide to the choice of surgical procedures in the management of chronic pancreatitis. Gastroenterology, 36, 224-231.

- (1961a). Surgery of pancreatic disease. In Modern Trends in Gastroenterology, 3rd series, edited by W. I. Card, pp. 264-299. Butterworths, London.

- (1961b). Book review on Surgical Disease of the Pancreas, edited by J. W. Howard and G. L. Jordan. Gastroenterology, 41, 54-55.
- , and Cattell, R. B. (1956). Basic techniques in pancreatic surgery. Surg. Clin. N. Amer., 36, 707-724.

_- and Veidenheimer, M. (1962). Pathological considerations in the choice of operation for chronic relapsing pancreatitis. New Engl. J. Med., 266, 323-329.

Waugh, J. M. (1959). Surgical aspects of pancreatitis. Gastroenterology, 36, 19-25.

White, T. T. (1965). Results of 89 operations for pancreatitis: a personal experience. Surgery, 58, 1061-1074.

- , and Magee, D. F. (1960). Perfusion of the dog pancreas with bile without production of pancreatitis. Ann. Surg., 151, 245250.

Wilkie, D. P. D. (1921). Chronic duodenal ileus. Brit. med. J., 2, 793-795.

Williams, H. U., and Busch, F. C. (1907). The aetiology and pathogenesis of acute pancreatitis. Trans. Ass. Amer. Phycns, 22 , 304-314.

Wilson, D. R., Loach, L. F. W., and Bogoch, A. (1962). Steatorrhea due to chronic pancreatitis and pancreatic atrophy following gastric surgery. Canad. med. Ass. J., 87, 9-15.

Wisniewski, C., Williams, H. T. G., and MacKenzie, W. C. (1963) An experimental study of pancreatitis following Polya gastrectomy. Canad. J. Surg., 6, 210-217.

Womack, N. A., Zeppa, R., and Irvin, G. L. (1963). The anatomy of gallstones. Ann. Surg., 157, 670-686.

Wright, R. B. (1958). Relapsing pancreatitis. Report of a case with unusual features. Brit. J. Surg., 45, 394-395. 